\title{
ACHIEVEMENT OF NATIONAL EDUCATION OBJECTIVES THROUGH THE RESEARCH OF STUDENT'S ENVIRONMENT AND EDUCATION CHARACTER
}

\author{
Suhendar, M.Pd \\ Lecturer of STIBA IEC Jakarta \\ Suhendar_success@yahoo.com
}

\begin{abstract}
The objectives of this research are to find out the result of achievement of national education objectives through environmental research of students and through the characteristics of education. This study used descriptive qualitative research. In connection to which, this research constitutes one of teacher's best endeavors to know the attainment of education objectives and to ensure that teaching and learning activity in the class runs well, hence, the quality of education for students in the society can be accordingly improved.
\end{abstract}

Key words: education character, achievement, descriptive qualitative

\section{A. INTRODUCTION}

\section{Background}

Importantly, teachers are involved in pedagogical process; teachers play an important role in the process of building students' education; teachers are part of the society's agent of change; the student's ideal characters building can be achieved if it is performed by qualified teachers. Teachers supposedly know comprehensively, what are the matters which can hamper the fulfillment of national education objectives, some of which are to know the conditions of students environment and the characteristic of education itself.

Upon the performance of this research, the writer hopes that the teachers can have a vision and mission in teaching, make an innovation in the concepts in teachings and learning activity, and is forcefully improved themselves to have power of 
integrity, cooperation and justice, energy of love and care for the development of education quality in Indonesia.

Law Number 20 year 2003 regarding National Education System, Article 3, national education goal is to develop the potency of student in order to become human being who have faith and piety to God Almighty, having noble behavior, healthy, knowledgeable, smart, creative, independent, and becomes a democratic and accountable citizen.

Principally, education is one of human's best effort to increase his/her life quality either in terms of affective, cognitive or psychomotor aspects, even in economic quality. Currently, education has become a very valuable investment for a success of human life development in the future because it constitutes a basic need for their lives. Consequently, it is necessary to plan education for the students properly so that the objectives of national education can be optimally achieved.

In connection to which, the achievement of education objectives is among the other things can be done by improving education quality in synergy starting from the lowest to the highest levels in the institutions that are directly related to education.

In view of that, the efforts to improve education quality must be done continuously and holistically because the development of Science and Technology run very fast, moreover, the globalization era currently is forcefully required students to involve in environmental condition of Indonesian society which is more tendentious to materialism and hedonism learnt by human through unstoppable information and technological sophistication.

Analysis of educational environment is highly needed to acknowledge to what extent environment affects the students in the achievement of education objective he/she is pursued.

\section{Objectives}

The objectives of this research are (1) to know the importance of achievement of national education objectives in developing both teacher's and student's education quality; (1) to identify why the achievement of national 
education objectives is very crucial in the society; and (3) to specify the chronological steps of achievement of national education objectives.

\section{Theoretical Framework}

\subsection{External Environment Analysis}

External environment is the society environment which has very broad scope, covers national even international scales. This environment can be observed in terms of several aspects among the other things are economic, political and technological aspects.

First, condition of Indonesia's macro society actually provides conducive climate for the establishment of learning society, this is based on the reality that in macroeconomic point of view, Indonesian society can still be said stable both politically and economically.

Second, macro-economic condition and economic growth of the society can be categorized progressively increasing with more equal life quality and guarantee for the fulfilment of the most basic needs. The emergence of modern markets such as many super markets / mini markets and malls in urban area are the sign that the society's economy wheel is rapidly advanced. However, this is evidently inversely proportional with micro-economic condition, there are still many of Indonesian society who live below poverty line and increasingly high education cost that becomes a quite influencing threat in the achievement of education objective in Indonesia.

Third, the political condition reflected in the society's political live is noticed more matured, unity in diversity increasingly appears in daily life. Even though it is seen small sparks in the body of political elites, this does not directly influence to the education development in Indonesia.

Considerably, technology development in general is actually very helpful to human in carrying out their activities in wide range of aspects particularly in terms of health and information, unfortunately, on the other hand, it is evidently noticed that technology contributes negative impact to the society, this is seen from the rampant criminal action (cybercrime), the occurrence of 
moral decadence, promiscuity and hedonism lifestyle resulting by irresponsible technology use. This gives great challenge for educational institution to overcome it accordingly.

\subsection{Internal Environment Analysis}

Noticeably, internal environment is a narrower society environment than external environment, this environment is micro and directly related to student in their daily life.

In social science theory, human internal environment is more influenced by family. In which the family institution particularly has 4 primary functions, namely affection function, socialization function, economic function and successor descent function.

Affective function or function of affection in family becomes the main basis in the achievement of education objective. Realistically, students who live in harmonious family relatively has better academic achievement than the students who live in broken home family.

Noticeably, function of socialization in the family will run well whenever student can have good interaction with the surrounding environment, make good social relation and harmonious life with the others. These will give good contributions psychologically in the achievement of the education objective.

In view of that, economic function is quite influencing the achievement of education objectives, even though there must be many possibilities that middle low economic circle can have good academic achievement.

\subsection{Implementation of Education Based on Environmental Analysis}

Prominently, from external and internal analysis towards the student environment, it is necessary to take some implementation steps in order to achieve the improvement of education quality especially at school level namely among the other things: 
1) Faith and Piety-based learning application as the basis of behaviour and the filtering tool towards the information obtained through technology.

2) Procurement of Information and Communication Technology (ICT) learning facility in technology application as well as the provision of education in the application and use of technology healthily and accountably.

3) Intensive cooperation and harmonious relation between school and parents can be established through regular meeting program.

4) Creative and innovative learning application to build student's learning interest.

5) Performance of extracurricular activity to accommodate interest and talent of all students.

6) Creation of cheap and qualified education and affordable for all circles of Indonesia society, or application of cross subsidy system.

7) Creation of conducive school organization work culture.

Other positive programs which can be applied in accordance with each environmental condition and education unit level. Role and all of education components is highly required in one vision, mission and purpose of qualified education as well as to participate in succeeding school programs in the effort of improving education quality in accordance with the principles of long life education and education for all.

\subsection{The Importance of Character Education in the Achievement of Education objectives}

Subsequently, for the achievement of education objective, as the bridge to achieve the objective of nation and state life, it requires a tough characteristic of Indonesia society, who have solid spiritual base, nationalism spirit and high national values. This is needed in view of the rapid development of technology that make foreign culture easily enters Indonesia uncontrollably. Consequently, it might gradually erode spiritual values, nationalism value and cultural value of the nation.

This is proven by the proliferation of criminal activities, the growth of separatist movements in regions which lead to disintegration action of the 
nation. The number of public brawl between regions caused by racism, even in the circle of students and educators also have spread bullying tradition or violence action such as beating, fighting, and others that shows the loss of nationalism values and the loss of the nation character that upholds humanity values as set forth in Pancasila.

\subsection{Methodology}

This study used in this research is decriptive research method that describes and interprets the characteristics of education.

B. Result and Discussion

Based on the literature review and researcher's observation, character education which is ideally expected to be embedded in the students are:
1) Religious,
10) Having the spirit of the nation
2) Honest
11) Loving the homeland
3) Tolerant
12) Appreciating the achievement
4) Discipline
13) Responsible
5) Hard work
14) Building cooperation/communication
6) Creative
15) Peaceful and tranquil
7) Independent
16) Like reading
8) Democratic
17) Having environmental awareness ; and
9) Curios
18) Having social awareness.

Essentially, the establishment of these 18 characters to the students, it is expected to create a comprehensive Indonesian people namely the people having equilibrium in spiritual, cognitive, affective and psychomotor, the human who has high nationalism spirit and have good problem solving in their live.

It is necessary to remember that character education is the character embedded continuously and holistically, involving all aspects of society starting from family up to the highest leaders in this state. It should not stop until the achievement 
of national civilization that is Baldatun Toyyibatun Wa Robbun Ghofur which means a prosperous and welfare country under the blessing of God Almighty.

It would be unfair if all components of nations in certain circle are demanded to comply with law for the sake of order of nation and state life, but on the other hand stakeholders are contra-productive against those matters. How many criminal cases ensnared the nations' officials, even it is committed by law enforcers.

Therefore the application of character education as the continuation of student environment analysis is necessary to be applied from school environment and the main role as the agent of change hereof is teacher.

Teacher is the frontline in the achievement of education objectives, as teacher directly faces students as the spearhead of the nation's future. How heavy is teacher's duty who have to risk his/her life for the future of this nation.

Particularly, several roles of teacher which can be applied in actualizing the character building and character education to students are:

1) Giving good example for students, especially in spiritual aspect.

2) Implementing such an effective teaching and learning activities and focus on the building of character education.

3) Running school program in familiarization of character formation for example worship congregation, Imtaq activity and spiritual tour.

4) Carrying out reading habit as the implementation of School Literacy Movement for all school members. For teachers this is also enriches knowledge and teaching material, as one of teacher's duties is to deliver and develop lesson material, in view of science is rapidly developing.

5) Making cooperation with various parties to organize various activities that aims to explore and to distribute interest and talent of students.

6) Building cooperation with wide range of parties in giving reward for students who has proven their achievements.

7) Facilitating the students having the achievement in higher competition forum.

8) Organizing various activities for students, either in the form of intracurricular or extracurricular program. 
If teacher can maximize the potency of students and apply it in such proper activities, it is expected that students will be made busy to develop their achievement. There is no more opportunity for them to waste time just for committing any negative thing. Thereafter, positive character which has been embedded to the students will also form a positive society in the environment. If this condition happens continuously, it is expected that Indonesia will become the nation having good character which is respected by all countries in this world.

\section{CONCLUSION}

In conclusion, by viewing the facts explained hereinabove, teacher's role is highly needed, in particular after the enforcement of character education in 2011. This indicates the Government seriousness in building character of student's properly needed, which is ready to encounter the challenge of globalization era which is full of competition between nations and to embed nationalism and cultural values of the nation.

\section{BIBLIOGRAPHY}

Brown, H. Douglas. Principles of Language Learning and Teaching.

San Francisco: Prentice Hall, 1991

Bereison, B. and G.A. Steiner. Human Behaviour, an Inventory of Scientific Findings New York: Harcourt, Brace \& World, Inc., 1979

Freeman, Donald. New Ways in Teacher Education, Virginia, USA:

Alexandrin, 1993

Koontz, Harold \& O'Donnel, Cyril. Management A Systems and contingency Analysis of Managerial Functions, Sixth Edition, Mc. Graw Hill, Inc., 1972

Amir Tengku Ramli, Erlin Trisyuliani, Pumping Teacher, Jakarta: Grhadhika Binangkit, 2003.

Ary H. Gunawan, Sosiologi Pendidikan :Suatu analisis sosiologi tentang pelbagai problem Pendidikan, Jakarta: Rineka Cipta, 2010. 
Bambang Warsita, Teknologi Pembelajaran: Landasan dan aplikasinya, Jakarta: Rineka Cipta, 2008.

H.A.R.Tilaar, Paradigma Baru Pendidikan Nasional, Jakarta: Rineka Cipta, 2010.

Isriani Hardini \& Dewi Puspitasari, Strategi Pembelajaran terpadu: Teori, konsep dan implementasi, Jogyakarta: Familia, 2012.

Suprijanto, Pendidikan Orang Dewasa, Jakarta: Bumi Aksara, 2007.

Yufiarti, Psikologi Pendidikan dan Penerapannya, Center for Human Capacity Development, Jakarta, 2009. 
